\title{
Dissolution test of herbal medicines containing Paullinia cupana: validation of methods for quantification and assessment of dissolution
}

\author{
Sandra Alves de Sousa ${ }^{1}$, Henrique Pascoa ${ }^{1}$, Edemilson Cardoso da Conceição ${ }^{1}$, Suzana Ferreira \\ Alves ${ }^{1}$, Danielle Guimarães Almeida Diniz ${ }^{2}$, José Realino de Paula ${ }^{1}$, Maria Teresa Freitas Bara ${ }^{1, *}$ \\ ${ }^{1}$ Laboratory of Research on Natural Products (LPPN), Faculty of Pharmacy, Federal University of Goiás, ${ }^{2}$ Laboratory of \\ Pharmaceutical Technology (Farmatec), Faculty of Pharmacy, Federal University of Goiás
}

\begin{abstract}
"Guaraná" (Paullinia cupana) is used as a physical activity enhancer and stimulator due to its methylxanthines and condensed tannins. The aim of this work was to evaluate the dissolution behavior of five herbal medicines in the form of capsules and tablets containing guaraná. Assay and dissolution methods were validated and results obtained allowed simultaneous marker quantification with precision, accuracy, selectivity and robustness. Findings showed that $100 \%$ of the herbal medicinal products analyzed did not provide satisfactory results concerning the presence of four markers, $60 \%$ had three markers (caffeine, catechin and epicatechin), while $40 \%$ had only caffeine at tested dosage forms. In addition, after 30 minutes, only capsule A showed at least $80 \%$ of the dissolved markers. In other capsules, marker dissolution did not exceed $60 \%$ whereas $60 \%$ of the samples had some characteristic pharmacotechnical problems. These results evidence the need for rigorous quality control to help ensure the therapeutic action of these drugs. To this end, dissolution studies are an essential tool for quality assurance of herbal medicines.
\end{abstract}

Uniterms: Herbal medicines/quality control. Herbal medicines/dissolution behavior. Medicinal plants. Guaraná/pharmacognosy. Paullinia cupana/pharmacognosy.

Guaraná (Paullinia cupana) é utilizado como revigorante e estimulante devido à presença de metilxantinas e taninos condensados. Este trabalho visou avaliar o comportamento de dissolução de cinco fitoterápicos, na forma de cápsulas e comprimidos, contendo guaraná. $\mathrm{O}$ método de quantificação e de dissolução foram validados e os resultados obtidos permitiram a quantificação dos marcadores simultaneamente, com precisão, exatidão, seletividade e robustez. Foi verificado que $100 \%$ dos fitoterápicos analisados encontravam em desacordo quanto à presença dos quatro marcadores, sendo que $60 \%$ apresentaram três marcadores (cafeína, catequina e epicatequina) e 40\% apresentaram somente a cafeína. Além disso, após o tempo de 30 minutos de ensaio foi possível observar que somente a cápsula A apresentou pelo menos $80 \%$ dos marcadores dissolvidos. Nas demais cápsulas o comportamento de dissolução apresentado pelos marcadores não ultrapassou $60 \%$ e, além disso, $60 \%$ das amostras apresentaram alguns problemas farmacotécnicos característicos. Frente aos resultados obtidos torna-se evidente a necessidade de um rigoroso controle de qualidade que contribua para assegurar a ação terapêutica desses medicamentos e, nesse sentido, o estudo de dissolução constitui uma ferramenta essencial para a garantia de qualidade dos fitoterápicos.

Unitermos: Fitoterápicos/controle de qualidade. Fitoterápicos/comportamento de dissolução. Plantas medicinais. Guaraná/farmacognosia. Paullinia cupana/farmacognosia.

*Correspondence: M. T. F. Bara. Laboratório de Pesquisa em Produtos Naturais (LPPN), Faculdade de Farmácia, Universidade Federal de Goiás. Praça Universitária, s/n, 74605-220 - Goiânia-GO, Brasil. E-mail: mbara@farmacia.ufg.br 


\section{INTRODUCTION}

Paullinia cupana Kunth. ("Guaraná") is a plant of the Sapindaceae family, native to the Brazilian Amazon. Dried and slightly toasted seeds are the most commonly used parts (Rates, 2002). This plant is widely employed in Brazilian traditional medicine, has been used in industrial and homemade drinks as stimulating tonics and in cosmetic preparations. Moreover, the plant is indicated in cases of exhaustion, nervous depression and migraine treatment (Moraes, Micke, Tavares, 2003).

The seeds of "guaraná" are characterized by the presence of methylxanthines, mainly caffeine and theophylline plus theobromine in smaller quantities, as well as condensed tannins such as catechin, epicatechin, procyanidin $\mathrm{B} 2$, procyanidin $\mathrm{B} 3$ and procyanidin $\mathrm{B} 4$, which are dimeric units composed of flavan-3-ol (Antonelli-Ushirobira et al., 2007). The stimulating property attributed to "guaraná" is mostly due to the presence of caffeine, while the tannins are responsible for its astringent flavor. Some studies have demonstrated its antioxidant, antiviral, antibacterial and slimicide activities, besides some enzymatic inhibition (Yamaguti-Sasaki et al., 2007).

For a herbal medicinal product to be safe and effective, among other factors, it requires rigorous quality control. In the case of solid oral dosage forms, certain parameters should be evaluated that involve an assessment of the dosage form, since some conditions and manufacturing processes may limit drug release and therefore its absorption, compromising pharmacological activity (Ansel, Popovich, Allen, 2000).

Due to their importance, dissolution tests are frequently used for synthetic drug quality control, but their use in natural product evaluation has not been widely adopted (Taglioli et al., 2001), which is a problem (Bempong, Houghton, 1992; Taglioli et al., 2001; Kressmann et al., 2002; Westerhoff et al., 2002; Sittichai et al., 2007; Kratz et al., 2008). A peculiarity of herbal medicines is the fact that in many cases the in vivo/in vitro biopharmaceutical characterization is hard due to their complex composition, high metabolism suffered by constituents in the plants itself, and because of the different, often difficult, methods for extraction involved (Emea, 2003), as well as for quantification of analytes in phytocomplex (Williamson, 2001).

In the present work, methods were developed and validated for both liquid chromatography as well as dissolution in order to evaluate the dissolution behavior of capsules and tablets of "guaraná" purchased from the local market, using the release of theophylline, caffeine, catechin and epicatechin, quantified by HPLC, as a parameter.

\section{MATERIALS AND METHODS}

\section{Samples}

The samples used were three brands of capsules and two of tablets containing "guaraná" randomly purchased from local shops (Goiânia-GO, Brazil).

The HPLC profile of an authentic sample of "guaraná" (dried fruit) identified by Prof Dr José Realino de Paula - FF/UFG, was performed to establish a specification for the analysis of the herbal medicines sold.

\section{Quantification of markers of "guaraná" by HPLC}

The method used for determination of methylxanthines (caffeine and theophylline) and tannins was based on that proposed by Saito et al. (2006), employed for the determination of epigallocatechin, epicatechin, catechin and caffeine in green tea samples.

A Varian ${ }^{\circledR}$ (Palo Alto, California, USA) liquid chromatograph Pro Star model equipped with a model Pro Star 410 automatic injection system, Pro Star 240 quaternary pump and model Pro Star 310 - UV-Visible detector, were used.

Chromatographic conditions were the following: RP $18,250 \times 4.6 \mathrm{~mm}, 5 \mu \mathrm{m}$ (Varian) chromatographic column at isocratic elution mode, wavelength at $274 \mathrm{~nm}$, injection volume of $20 \mu \mathrm{L}$ (performed in duplicate), mobile phase flow of $1 \mathrm{~mL} / \mathrm{min}$ and mobile phase consisting of Water: Acetonitrile: Methanol: Ethyl acetate: Acetic acid (89: 6: 1:3:1). The standards used were caffeine anhydrous (99\%), catechin hydrate $(96 \%)$, epicatechin $(90 \%)$ and teophylline anhydrous (99\%), purchased from Sigma Aldrich.

To perform caffeine, theophylline, catechin and epicatechin assay, samples were prepared according to the Farmacopeia Brasileira (2003), except for the different solvent used for determination of methylxanthines (solution of hydrochloric acid $0.1 \mathrm{M}$ ). To prepare samples, the average weight of capsules and tablets was first determined according to the Farmacopeia Brasileira (1988). For the quantification of the markers, the equivalent of $250 \mathrm{mg}$ of herbal content was weighed and transferred to a $100 \mathrm{~mL}$ volumetric flask. After being subjected to a mechanical horizontal shaker for $15 \mathrm{~min}$ with four portions of $20 \mathrm{~mL}$ of $0.1 \mathrm{M}$ hydrochloric acid for extraction of methylxanthines and tannins, the volume of the flask was supplemented with $0.1 \mathrm{M}$ hydrochloric acid. The sample was filtered using filter paper and injection was performed in duplicate for chromatography.

The calculation of the content of caffeine, theo- 
phylline, catechin and epicatechin was performed using the following formula:

$$
\%=\frac{\mathrm{SA} \times \mathrm{SC} \times \mathrm{DF} \times 100}{\mathrm{SA}^{\prime} \times \mathrm{W}}
$$

In which: $\mathrm{SA}=$ sample area; $\mathrm{SA}^{\prime}=$ standard area; $\mathrm{SC}=$ standard concentration $(\mathrm{mg} / \mathrm{mL}) ; \mathrm{DF}=$ dilution factor; $\mathrm{W}=$ sample weight in $\mathrm{mg}$.

\section{Chromatographic method validation}

The validation of the analytical method for quantification of theophylline, caffeine, catechin and epicatechin in "guaraná" by HPLC was performed according to RE No. 899/2003 ANVISA (Brazil, 2003). The parameters evaluated were selectivity, linearity and range, precision (repeatability and intermediate), accuracy and robustness.

Selectivity was determined by analyzing the chromatographic profile (retention time and resolution) of the samples (capsules and tablets), standard compounds and solvent, $\mathrm{HCl} 0.1 \mathrm{M}$ (blank) in order to verify possible interference.

The linearity was determined for each marker by injecting six different concentrations of the standard mixture into the HPLC apparatus. The solutions of the standards (theophylline, caffeine, catechin and epicatechin) were prepared in methanol, followed by serial dilution to achieve concentrations ranging from $0.5 \mu \mathrm{g} / \mathrm{mL}$ to $15.0 \mu \mathrm{g} / \mathrm{mL}$.

Precision (repeatability) was determined by preparing and analyzing six replicates of the sample at $100 \%$ concentration. For this procedure, samples were prepared accordingly to the method described above. The results were expressed as relative standard deviation (RSD\%).

Precision (intermediate) was determined by analyzing the sample in triplicate at $100 \%$ on two days and by two different analysts. For this procedure, samples were prepared accordingly to the method described above. The results were again expressed as relative standard deviation (RSD\%).

Accuracy determination was undertaken by analyzing the sample in triplicate at the concentrations of 50,100 and $150 \%$, and was verified by the recovery procedure, i.e. verification of the differences between the averages of these values and the theoretical value found.

The robustness of the method was evaluated in triplicate using the following parameters: wavelength of the reading at $272 \mathrm{~nm}, 274 \mathrm{~nm}$ and $276 \mathrm{~nm}$, and flow of the mobile phase at $0.8 \mathrm{~mL} / \mathrm{min}, 1.0 \mathrm{~mL} / \mathrm{min}$ and $1.2 \mathrm{~mL} / \mathrm{min}$. The result was expressed as relative standard deviation (RSD\%).

\section{Dissolution test}

The analytical methodology used to evaluate dissolution followed United States Pharmacopeia (2007) specifications, which describe the general methodology for capsule and tablet dissolution tests. Tests were carried out on a Vankel VK 7000 Total Solution Dissolution device using USP apparatus 2 (paddle), $\mathrm{HCl} 0.1 \mathrm{M} \mathrm{pH} 1.2$ medium, dissolution vessel volume of $900 \mathrm{~mL}, 37.5 \pm 0.5^{\circ} \mathrm{C}$ temperature, stirring speed of $75 \mathrm{rpm}$, and sampling aliquots of $3 \mathrm{~mL}$ withdrawn at $0,5,10$ and 30 minutes. Samples were automatically collected, filtrated and assayed by HPLC.

\section{Validation of dissolution method}

The dissolution test is classified according to its purpose in test category III, hence the need for validation assessment of the precision parameter by means of repeatability (Brazil, 2003).

The precision evaluated at the repeatability level was determined by analysis of six individual samples (six replicates) collected from dissolutor at a time of $30 \mathrm{minu}-$ tes. The repeatability was expressed as relative standard deviation between samples (RSD\%).

\section{RESULTS AND DISCUSSION}

\section{Validation of HPLC method for quantification of markers for $P$. cupana}

The selection of the wavelength of $274 \mathrm{~nm}$ was made by assessing the absorption spectra in the UV range of methylxanthines (theophylline and caffeine), catechin and epicatechin.

The choice of mobile phase $\mathrm{pH}$ was based on the $\mathrm{pKa}$ of the substances being eluted. The $\mathrm{pKa}$ of methylxanthines can vary from 8.4 to 13.9 and of catechins from 8.6 to 13.2 (Gennaro, 2004). The $\mathrm{pH}$ of the mobile phase must be below the ionization constant, because the increased ionized analyte raises its dissolution in the aqueous phase and reduces its retention time, since the ionic form passes through the column without retention (Ivanovic et al., 1995).

The HPLC method used was linear, selective, precise, accurate and robust for the four markers present in the "guaraná", namely, theophylline, caffeine, catechin and epicatechin.

The method of identification and quantification of methylxanthines, catechin and epicatechin by high performance liquid chromatography was selective because it is 
capable of separating the markers, as shown in Figure 1. The data shows that the solution used for dilution of the markers does not interfere with the peak of the markers in the sample.

For the markers quantified, the method was linear with a value of $\mathrm{r}^{2}=0.9992$ for theophylline $(\mathrm{y}=0.36074 \mathrm{x}$ $+1.11898), 0.9979$ for caffeine $(y=0.37758 \mathrm{x}+0), 0.9982$ for catechin $(y=0.08182 \mathrm{x}+0)$, and 0.9990 for epicatechin $(\mathrm{y}=0.07145 \mathrm{x}+0)$.

The method was shown to be precise for quantification of the four markers, in both repeatability and intermediate precision, with RDS $<5 \%$ (Table I).

The method was shown to be accurate for theophylline, caffeine, catechin and epicatechin, with recovery values ranging from $95.18 \%$ to $104.11 \%$.
The method was robust since it resisted slight wavelength variations $(272,274$ and $276 \mathrm{~nm})$; and mobile phase flow variations $-0.8 ; 1.0$ and $1.2 \mathrm{~mL} / \mathrm{min}$ for the theophylline, caffeine, catechin and epicatechin evaluated. RSD values were less than 5\%.

\section{Quantification of markers of $P$. cupana}

A large variation in the percentage of the caffeine marker ( 1.32 to $6.51 \%$ ) was observed among the five herbal samples analyzed, which was not related to the catechin and epicatechin (Table II, Figure 2). Given the stimulant activity of "guaraná" is mainly due to the presence of caffeine (Yamaguti-Sasaki et al., 2007), the non-uniformity in the

TABLE I - Precision of HPLC method for quantification of markers of $P$. cupana

\begin{tabular}{lcc}
\hline & Repeatability & \\
\hline Marker & Mean Concentration/ RSD $(\mu \mathrm{g} / \mathrm{mL})$ & Mean $\%$ \\
\hline Theophylline & $0.2599 / 4.46$ & 0.1039 \\
Caffeine & $14.55 / 1.74$ & 5.82 \\
Catechin & $2.04 / 3.17$ & 0.82 \\
Epicatechin & $1.84 / 4.01$ & 0.73 \\
\hline & Intermediate precision \\
\hline Theophylline & $0.2297 / 3.61$ & 0.0919 \\
Caffeine & $14.70 / 1.85$ & 5.88 \\
Catechin & $2.01 / 2.80$ & 0.80 \\
Epicatechin & $1.91 / 4.16$ & 0.77 \\
\hline
\end{tabular}

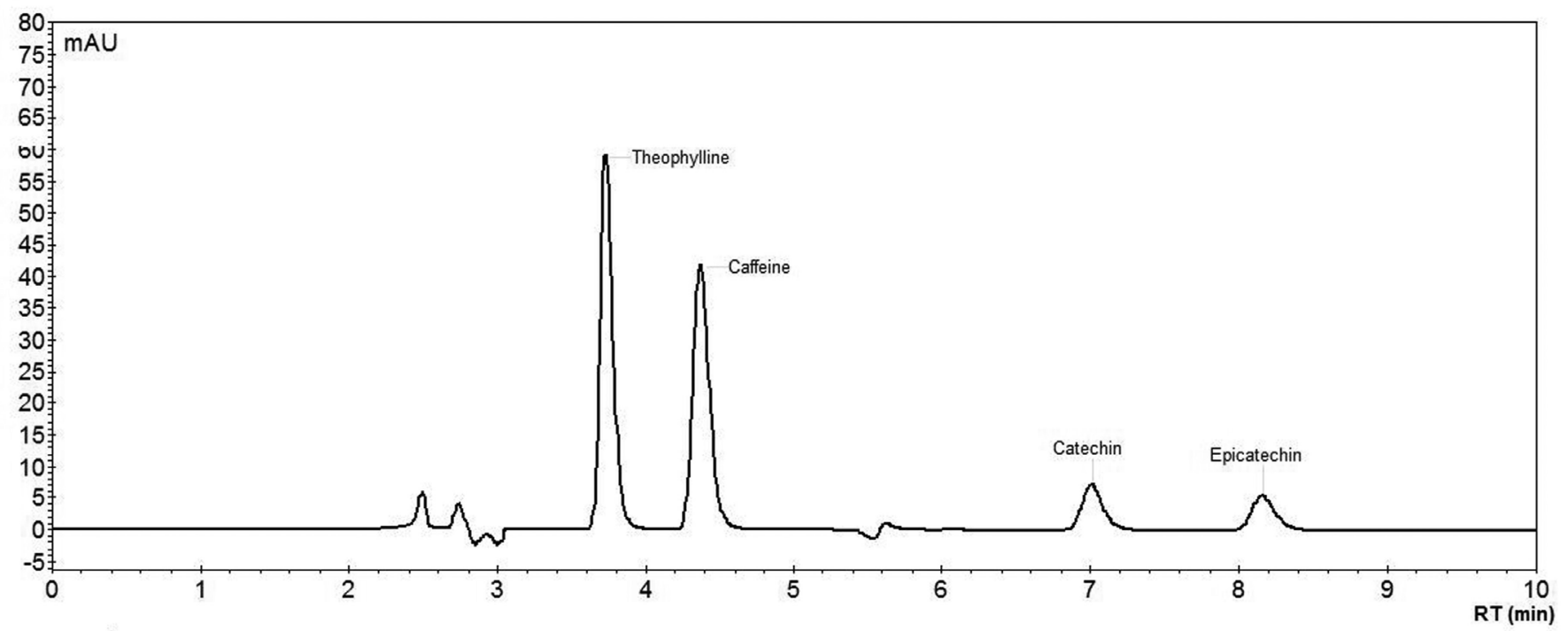

FIGURE 1 - Theophylline, caffeine, catechin and epicatechin standard solution chromatogram. Chromatographic conditions: water, acetonitrile, methanol, ethyl acetate and acetic acid (89:6:1:3:1) mobile phase; isocratic elution; flow of $1 \mathrm{~mL} / \mathrm{min}$; Varian ${ }^{\circledR} \mathrm{RP} 18$ $250 \times 4.6 \mathrm{~mm}, 5 \mu \mathrm{m}$ column; and detector at $274 \mathrm{~nm}$. 
TABLE II - Percentage of markers in capsules and tablets of $P$. cupana analyzed

\begin{tabular}{lcccc}
\hline Samples & \multicolumn{3}{c}{ Markers } \\
\cline { 2 - 5 } & Caffeine & Theophylline & Catechin & Epicatechin \\
\hline Capsule A & $2.37 \%$ & 0.0 & $0.49 \%$ & $0.49 \%$ \\
Capsule B & $3.36 \%$ & 0.0 & $0.60 \%$ & $0.68 \%$ \\
Capsule C & $6.51 \%$ & 0.0 & 0.0 & 0.0 \\
Tablet A & 0.0 & 0.0 & 0.0 \\
Tablet B & $2.64 \%$ & 0.0 & $0.34 \%$ & $0.41 \%$ \\
\hline
\end{tabular}

A - Capsule A

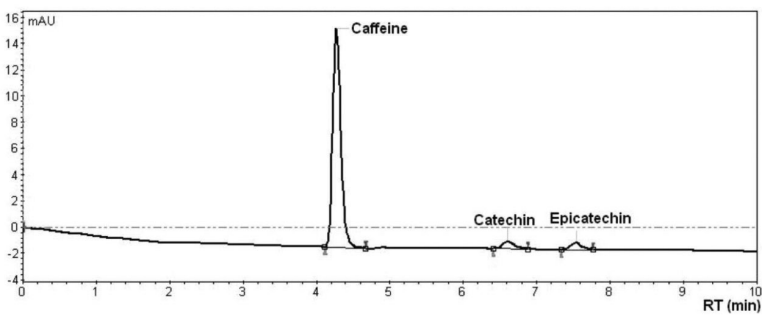

B - Capsule B

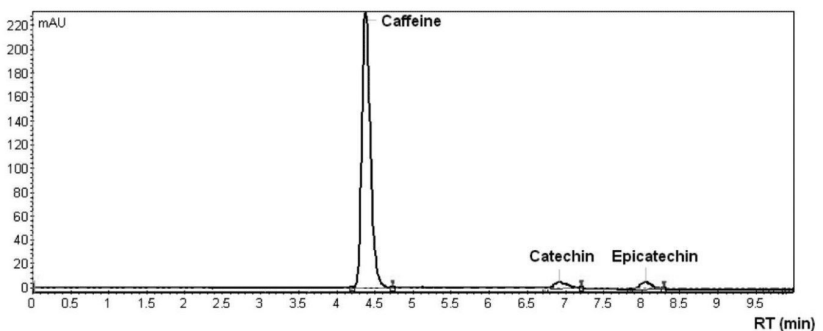

D - Tablet A

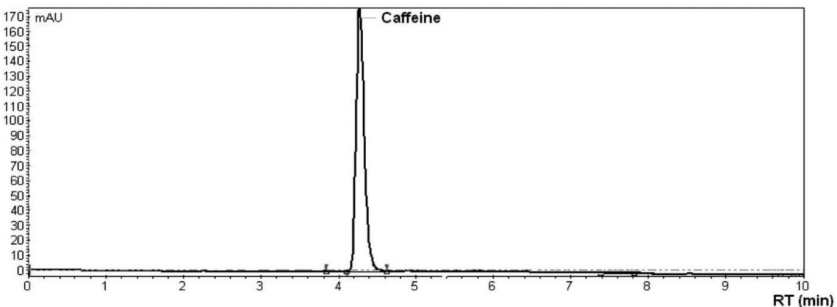

E - Tablet B

C - Capsule C
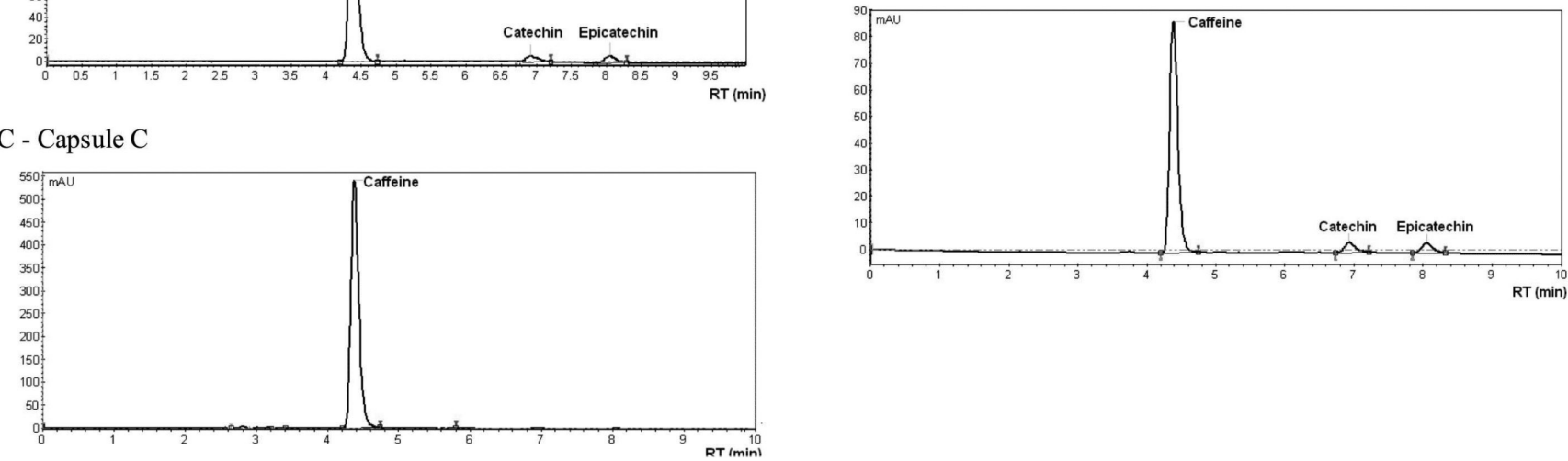

FIGURE 2 - Herbal medicine chromatogram. Chromatographic conditions: water, acetonitrile, methanol, ethyl acetate and acetic acid (89:6:1:3:1) mobile phase; isocratic elution; flow of $1 \mathrm{~mL} / \mathrm{min}$; Varian ${ }^{\circledR} \mathrm{RP} 18250 \times 4.6 \mathrm{~mm}$, $5 \mu \mathrm{m}$ column; and detector at 274 nm. A- Capsule A, B - Capsule B, C- Capsule C, D - Tablet A, E-Tablet B.

concentration of this drug reveals a problem in relation to the dosage used and efficiency of this herbal medicine.

Thus, it is noteworthy that one of the great challenges faced by the botanical drugs market is the standardization of biological materials from natural sources. New technologies to modernize traditional herbs into mainstream pharmaceutical products are being evaluated with the goal of maximizing the opportunities and overcoming the challenges (Liu, Wang, 2008).

\section{Validation of dissolution method:}

The method was shown to be precise for the quantification of four markers, in repeatability precision, with aliquots being removed at the 30 -minute timepoint, and RDS $<5 \%$. For theophylline, the percentage was 0.0986 , SD 0.0023 with RSD of 2.37. For caffeine, the percentage was 6.22 , SD 0.08 and RSD 1.38. For catechin, the percentage was 0.88 , SD 0.02 and RSD 3.04. Finally, 
for epicatechin, the percentage was 0.72 , SD 0.03 and RSD 4.39.

\section{Dissolution test}

None of the five samples of herbal medicines analyzed showed satisfactory results regarding dissolution profile and presence of the four proposed markers (Table III, Figure 3).

After 30 minutes, capsule A presented at least $80 \%$ of the markers dissolved (Figure $3 \mathrm{~A}$ ). In the other capsules, the dissolution profile presented by the markers, when present, did not exceed $60 \%$ (Figures $3 \mathrm{~B}$ and C), probably due to formulation problems such as excipients and handling process used. Among the tablets, sample A reached $100 \%$ dissolution for caffeine, and was the only marker detected (Figure 3D). In tablet B, possibly due to pharmacotechnical problems, e.g. strength compression, its total disintegration, and consequently its total dissolution, did not occur, not releasing more than $40 \%$ of the markers assayed (Figure 3E).

The drug manufacturing processes and formulation components involved can influence dissolution and bioavailability. Tablets obtained by direct compression, dry or wet granulation, may display different in vitro and in vivo behavior. These factors directly affect dosage form disaggregation in gastrointestinal fluids, influencing dissolution and consequently, drug absorption (Storpirtis et al., 1999).
The results of this study also demonstrated that among the samples, $60 \%$ had three markers present (caffeine, catechin and epicatechin) (Figures 3A, B and E) while $40 \%$ had only caffeine as a marker (Figures 3C and D). Since catechin, epicatechin and theophylline are markers of P. cupana (Farmacopeia Brasileira, 2003; Antonelli-Ushirobira et al., 2007) its absence in some samples point to a quality problem. Furthermore, only the presence of caffeine in some herbal medicines analyzed is an important non-compliance. This result suggests the poor quality of these herbal medicines and possible adulteration by sophistication practices, for example, the addition of synthetic caffeine $P$. cupana powder. Sophistications practices are difficult to detect and occur usually by addition of synthetic or natural substances with structures similar to those of the active principle, medicinal plants or herbal products with low quantity of active principle, in order to fool quality control (Sharapin, 2000; Rocha, 2009). Moreover, for quality assurance purposes, desirable attributes include authenticity and purity. Authenticity relates to proving that the material is genuine and involves parameters including chemical analysis. Purity pertains to evaluating that there are no adulterants present in the plant material (Yadav, Dixit, 2008).

Another important aspect to highlight is that considering solid oral medicines can present major problems in relation to bioavailability, it is important to evaluate the dissolution of the drug from the dosage form by per-

TABLE III - Percentage of dissolution versus time for herbal medicines tested

\begin{tabular}{|c|c|c|c|c|c|}
\hline & \multicolumn{5}{|c|}{$\%$ Dissolution (mean) } \\
\hline & time & theophylline $( \pm \mathrm{SD})$ & caffeine $( \pm$ SD) & catechin $( \pm \mathrm{SD})$ & epicatechin $( \pm \mathrm{SD})$ \\
\hline \multirow[t]{3}{*}{ Capsule A } & 5 & 0.00 & $41.50( \pm 1.95)$ & $34.90( \pm 0.47)$ & $42.71( \pm 0.51)$ \\
\hline & $10^{\prime}$ & 0.00 & $70.05( \pm 1.76)$ & $56.64( \pm 0.35)$ & $69.60( \pm 0.40)$ \\
\hline & $30^{\prime}$ & 0.00 & $102.25( \pm 2.07)$ & $79.59( \pm 0.51)$ & $101.31( \pm 0.48)$ \\
\hline \multirow[t]{3}{*}{ Capsule B } & 5 & 0.00 & $19.60( \pm 1.25)$ & $15.17( \pm 0.18)$ & $21.50( \pm 0.31)$ \\
\hline & $10^{\prime}$ & 0.00 & $34.92( \pm 2.27)$ & $26.72( \pm 0.28)$ & $37.37( \pm 0.48)$ \\
\hline & $30^{\prime}$ & 0.00 & $59.88( \pm 1.82)$ & $42.90( \pm 0.31)$ & $55.84( \pm 0.37)$ \\
\hline \multirow[t]{3}{*}{ Capsule C } & 5 & 0.00 & $0.05( \pm 0.01)$ & 0.00 & 0.00 \\
\hline & $10^{\prime}$ & 0.00 & $0.97( \pm 0.07)$ & 0.00 & 0.00 \\
\hline & $30^{\prime}$ & 0.00 & $18.28( \pm 4.44)$ & 0.00 & 0.00 \\
\hline \multirow[t]{3}{*}{ Tablet A } & 5 & 0.00 & $59.86( \pm 0.82)$ & 0.00 & 0.00 \\
\hline & $10^{\prime}$ & 0.00 & $99.96( \pm 0.33)$ & 0.00 & 0.00 \\
\hline & $30^{\prime}$ & 0.00 & $106.49( \pm 0.29)$ & 0.00 & 0.00 \\
\hline \multirow[t]{3}{*}{ Tablet B } & 5 & 0.00 & $6.98( \pm 0.15)$ & $2.91( \pm 0.03)$ & $5.62( \pm 0.11)$ \\
\hline & $10^{\prime}$ & 0.00 & $12.95( \pm 0.15)$ & $8.82( \pm 0.08)$ & $10.84( \pm 0.05)$ \\
\hline & 30 ' & 0.00 & $39.93( \pm 0.47)$ & $33.02( \pm 0.13)$ & $34.43( \pm 0.17)$ \\
\hline
\end{tabular}




\section{A - Capsule A}

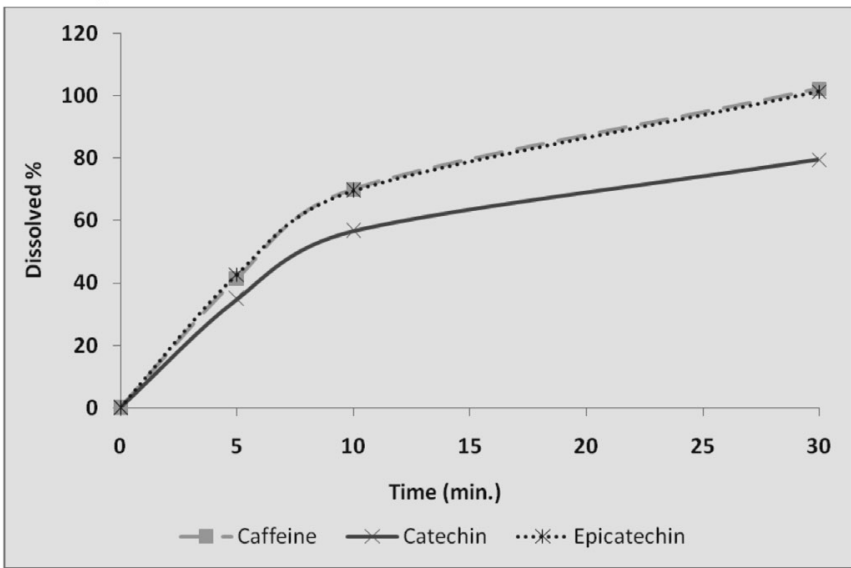

\section{B - Capsule B}

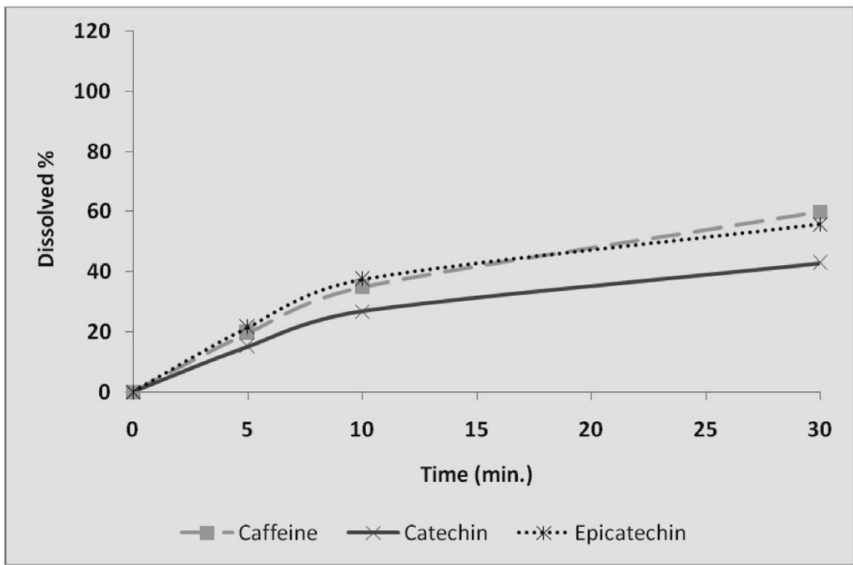

\section{C - Capsule C}

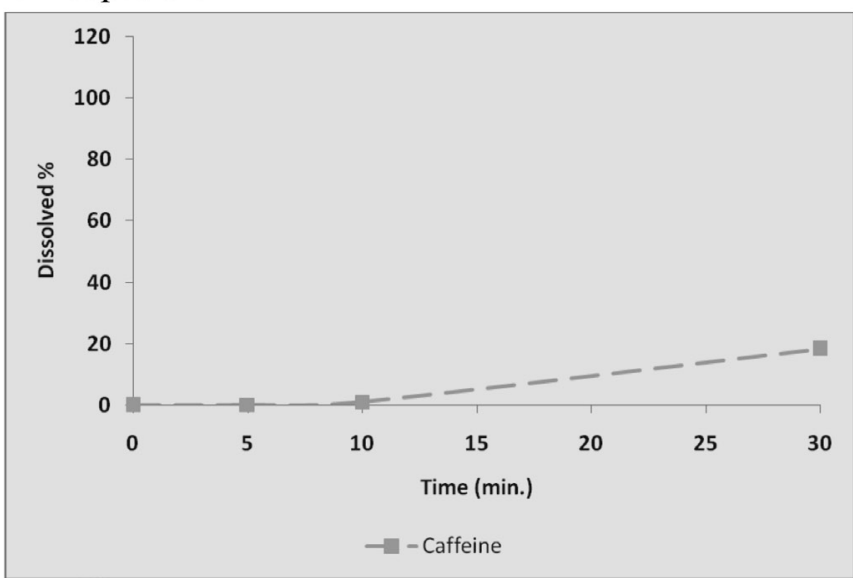

D - Tablet A

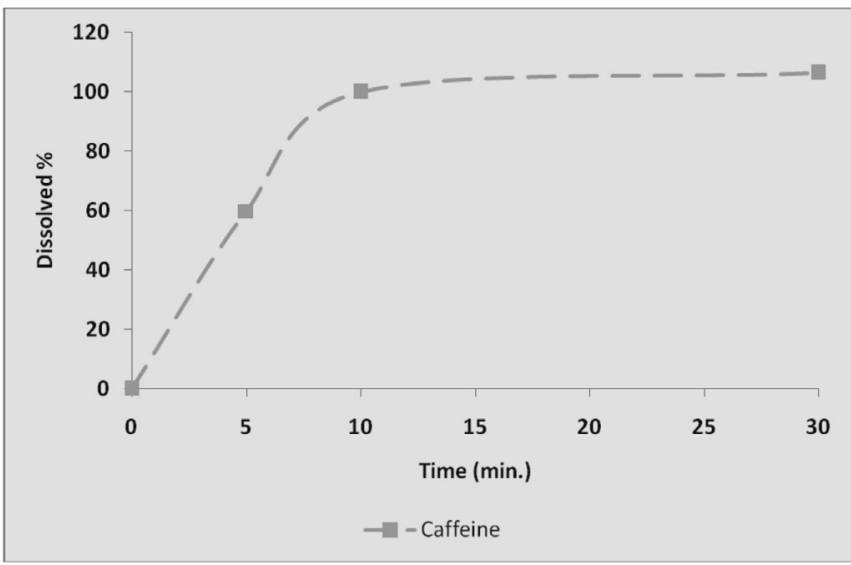

E - Tablet B

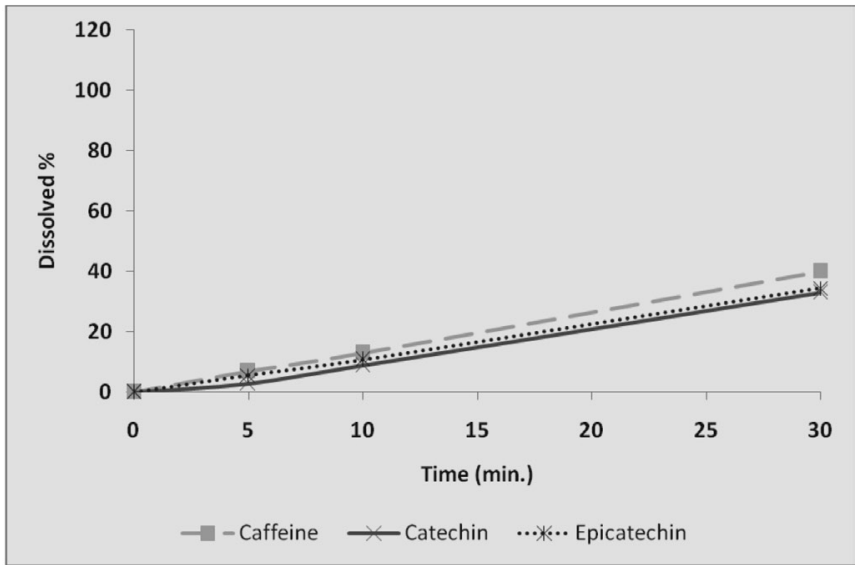

FIGURE 3 - Dissolution profile of herbal medicines of P. cupana, using apparatus 2 (paddle), $\mathrm{HCl} 0.1 \mathrm{M} \mathrm{pH} 1.2$ medium, dissolution vessel volume of $900 \mathrm{~mL}, 37.5 \pm 0.5^{\circ} \mathrm{C}$ temperature, stirring speed of $75 \mathrm{rpm}$, at $0,5,10$ and 30 minutes. A- Capsule A, B - Capsule B, C- Capsule C, D - Tablet A, E - Tablet B.

forming in vitro tests that help to visualize the dissolution profile as a function of time.

Literature has demonstrated concerning data related to herbal medicinal product dissolution tests. A study performed with phytomedicines based on Ginkgo biloba demonstrated that $85 \%$ of the evaluated products failed to have the recommended chemical composition and therefore their use could not be indicated (Kratz et al., 2008). In another study on Ginkgo biloba extract capsules and tablets, marked differences in dissolution behavior were 
found, with values of $99 \%$ and $33 \%$ dissolution, on average, after 15 minutes and 1 hour, respectively (Kressmann et al., 2002). The dissolution profile of Senna sp was less than $10 \%$ sennoside release from capsules containing dry extract, in a period of 60 minutes, in contrast to lyophilized Senna sp extract, which attained around $90 \%$ dissolution after the same period. Data on the dissolution test of Passiflora sp showed that capsules containing the crude extract presented $50 \%$ dissolution while lyophilized extract and other standardized extract reached around $100 \%$ for the same period (Taglioli et al., 2001).

Considering the increasing consumption of herbal medicines, $P$. cupana included, there is a need for studies to ensure quality from raw material to finished product. Quality control is essential for the efficacy and safety of herbal products. Thus, dissolution studies are of great importance since they can contribute toward ensuring the effectiveness of herbal medicines.

\section{CONCLUSION}

The results showed that the quality of herbal medicines containing "guaraná" represents a serious public health problem, since $100 \%$ of the samples analyzed differed in terms of the presence of chemical markers of the drug both on the dissolution test as well as in relation to pharmacotechnical aspects.

\section{REFERENCES}

ANSEL, H.C.; POPOVICH, N.G.; ALLEN JR, L.V. Formas farmacêuticas e sistemas de liberação de fármacos. Baltimore: Editorial Premier, 2000. 568 p.

ANTONELLI-USHIROBIRA, T.M., YAMAGUTI, E.; UHEMURA, L.M.; NAKAMURA, C.V.; DIAS FILHO, B.P.; MELLO, J.C.P. Chemical and microbiological study of extract from seeds og guaraná (Paullinia cupana var. sorbilis). Lat. Am. J. Pharm., v.26, p.5-9, 2007.

BEMPONG, D.K.; HOUGHTON, P.J. Dissolution and absortion of caffeine from guaraná. J. Pharm. Pharmacol., v. 44, p.769-771, 1992.

BRASIL. MS, ANVISA. Resolução no 899 de 29/05/2003. Determina a publicação do "Guia para validação de métodos analíticos e bioanalíticos". Diário Oficial da União da República Federativa do Brasil, Brasília- DF, 02 de junho de 2003. Seção 1, p.56-59.
EUROPEAN AGENCY FOR THE EVALUATION OF MEDICINAL PRODUCTS. EMEA. Points to consider on the biopharmaceutical characterisation of herbal medicinal products. 2003. Available at: $<$ http://www.emea.eu.int $>$. Accessed on: 13 jun. 2008.

FARMACOPEIA BRASILEIRA. São Paulo: Atheneu, 1988. p.V.1.1.1 - V. 1.1.3.

FARMACOPEIA BRASILEIRA. São Paulo: Atheneu, 2003. p.236-240.

IVANOVIC, D.; MEDENICA, M.; NIVAUD-GUERNET, E.; GUERNET, M. Effect of $\mathrm{pH}$ on the retention behaviour of some preservatives-antioxidants in reversed-phase highperformance liquid chromatography. Chromatographia, v.40, p.652-656, 1995.

GENNARO, A.R. Remington: a ciência e a prática da farmácia. 20.ed. São Paulo: Guanabara Koogan, 2004. 2208 p.

KRATZ, J.M.; TERRAZAS, C.B.; MOTTA, M.J.; REGINATTO, F.H.; SIMÕES, C.M.O. Determinação da composição química e dos perfis de dissolução in vitro de medicamentos à base de Ginkgo biloba disponíveis no mercado brasileiro. Lat. Am. J. Pharm., v.27, p.674-680, 2008.

KRESSMANN, S.; BIBER, A.; WONNEMANN, M.; SCHUG, B.; BLUME, H.H.; MULLER, W.E. Influence of pharmaceutical quality on the biovailability of active components from Ginkgo biloba preparations. J. Pharm. Pharmacol., v.54.p.1507-1514, 2002.

LIU, Y.; WANG, M.W. Botanical drugs: challenges and opportunities. Life Sci., v.82, p.445-449, 2008.

MORAES, M.L.; MICKE, G.A.; TAVARES, M.F.M. Separação e análise de metilxantinas em extratos de guaraná e ervamate por eletroforese capilar. Rev. Analytica, v.5, p.44-50, 2003.

RATES, S.M.K. Metilxantinas. In: SIMÕES, C.M.O.; SCHENKEL, E.P.; GOSMAN, G.; MELLO, J.C.P; MENTZ, L.A.; PETROVICK, P.R. (Eds.). Farmacognosia: da planta ao medicamento. 4.ed. Porto Alegre/Florianópolis: Ed. UFRGS/Ed. UFSC, 2002. Cap.23, p.733-749.

ROCHA, L. M. Controle de qualidade de drogas vegetais e fitoterápicos. In: LEITE, J. P. V. (Eds.).Fitoterapia: Bases cientificas e tecnológicas. 1.ed. São Paulo: Editora Atheneu, 2009. Cap.9, p.253-276. 
SAITO, S.T.; WELZEL, A.; SUYENAGA, E.S.; BUENO, F. A Method for fast determination of eigallocatechin gallate (EGCG), epicatechin (EC), catechin (C) and caffeine (CAF) in green tea using HPLC. Rev. Cienc. Tecnol. Aliment., v.26, p.394-400, 2006.

SITTICHAI, N.; KARABESRI, S.; SUTHISON, E.; TENGAMNUAY, P. An approach to developing dissolution standards for turmeric capsules in basket rotating method. Thai J. Pharm. Sci., v.31, p.83-90, 2007.

SHARAPIN, N. Controle de qualidade de plantas medicinais e fitofármacos - prescrições farmacopéicas. In: SHARAPIN, N. (Ed.). Fundamentos de tecnologia de produtos fitoterápicos. Colombia: Cyted, 2000. Cap.11, p.145-157.

STORPIRTIS, S.; OLIVEIRA, P.G.; RODRIGUES, D.; MARANHO, D. Considerações biofarmacotécnicas relevantes na fabricação de medicamentos genéricos: fatores que afetam a dissolução e a absorção de fármacos. Braz. J. Pharm. Sci., v.35, p.1-16, 1999.

TAGLIOLI, V.; BILIA, A.R.; GHIARA, C.; MASSI, G.; MERCATI, V.; VINCIERI, F.F. Evaluation of the dissolution behaviour of some commercial herbal drugs and their preparations. Pharmazie, v.56, p.868-870, 2001.
UNITED STATES PHARMACOPEIA. The Official Compendia of Standards. Rockville: Editora, 2007. 1122 p.

YADAV, N.P.; DIXIT, V.K. Recent approaches in herbal drug standardization. Int. J. Integr. Biol., v.2, p.195-203, 2008.

YAMAGUTI-SASAKI, E.; ITO,L.A.; CANTELI, V.C.D.; ANTONELLI-USHIROBIRA, T.M.; UEDANAKAMURA, T.; FILHO, B.D.; NAKAMURA, C.V.; MELLO, J.C.P Antioxidant capacity and in vitro prevention of dental plaque formation by extracts and condensed tannins of Paullinia cupana. Molecules, v.12, p.1950-1963, 2007.

WESTERHOFF, K.; KAUNZINGER, A.; WURGILICS, M.; DRESSMAN, J.; SHUBERT, M.Z. Biorelevant dissolution testing of St. John's wort products. J. Pharm. Pharmacol., v.54, p.1615-1621, 2002.

WILLIAMSON, E. M. Synergy and other interactions in phytomedicines. Phytomedicine, v.8, p.401-409, 2001.

Received for publication on $12^{\text {th }}$ April 2010. Accepted for publication on $14^{\text {th }}$ July 2010. 